\title{
Hubungan kualitas Website UPI Central Library dengan kepuasan pengguna
}

\author{
Ricky Hardiyanto a*, Ninis Agustini Damayani ${ }^{\mathrm{b}}$, Edwin Rizal $^{\mathrm{c}}$ \\ ${ }^{a b c}$ Fakultas Ilmu Komunikasi Universitas Padjadjaran Bandung
}

\begin{abstract}
Abstrak
Perkembangan zaman dan peranan teknologi informasi menuntut perpustakaan untuk berinovasi, salah satu inovasi yang dilakukan perpustakaan adalah website. Kualitas website saat ini menjadi suatu isu strategis yang digunakan dalam komunikasi dan interaksi dengan pengguna. Penelitian ini bertujuan untuk mengetahui sejauh mana keterkaitan kualitas web UPI Central Library dengan kepuasan pengguna, khususnya mahasiswa strata 1 di Universitas Pendidkan Indonesia Kampus Bumi Siliwangi. Salah satu metode yang digunakan untuk mengukur kualitas dari suatu web adalah WebQual. Penelitian ini menggunakan metode WebQual 4.0 sebagai dasar pengukuran kualitas web yang dikemukakan Barnes \& Vidgen yang terdiri dari kualitas ketergunaan yaitu kategori pengukuran situs web yang mencakup kemudahan ketergunaannya, kualitas informasi yaitu kategori yang mengkaji isi dan kualitas informasi atau konten secara umum yang mencakup kelayakan informasi tersebut, dan kualitas layanan interaksi yaitu kategori pengukuran kualitas website melalui interaksi layanan yang dirasakan oleh pengguna. Sedangkan untuk pengukuran kepuasan pengguna menggunakan teori importance-performance analysis dari Martilla dan James yang terdiri dari apa yang diinginkan atau diharapkan pengguna atau tingkat kepentingan pengguna (importance) dan apa yang dirasakan pengguna atau tingkat kinerja website (performance). Metode yang digunakan dalam penelitian ini adalah metode penelitian kuantitatif dengan pendekatan korelasional. Uji korelasi dilakukan dengan metode korelasi Pearson Product Moment yang bertujuan untuk menguji hubungan sebab akibat antara variabel $\mathrm{X}$ dan $\mathrm{Y}$. Teknik pengumpulan data menggunakan kuesioner, wawancara dan studi literatur. Pengambilan sampling dilakukan dengan teknik sampel acak sederhana (simple random sampling) menggunakan populasi sebanyak 27.172 mahasiswa dan responden sebanyak 394 mahasiswa. Hasil penelitian ini menunjukkan bahwa kualitas website UPI Central Library terhadap kepuasan pengguna memiliki hubungan signifikan yang moderat artinya semakin tinggi kualitas web maka akan semakin tinggi pula kepuasan yang diterima.
\end{abstract}

Kata kunci: Kualitas website; UPI Central Library; Kepuasan Pengguna; Universitas Pendidikan Indonesia

Korespondensi: Ricky Hardiyanto, Fakultas Ilmu Komunikasi, Universitas Padjadjaran, Jl. Ir. Soekarno Km. 21, Jatinangor, Sumedang, Jawa Barat 45363, Indonesia

Email: hardiyantoricky7@gmail.com

http://jurnal.unpad.ac.id/informatio

DOI: https://doi.org/10.24198/inf.v1i2.33605

Received: April 2021; Accepted: Juli 2021; Published: Juli 2021

(C) Informatio 2021. This is an open access article under the CC BY-SA license 


\title{
UPI Central Library's Website quality relationship with user satisfaction
}

\begin{abstract}
The times and the role of information technology require libraries to innovate, one of the innovations made by libraries is a website. Website quality is currently a strategic issue that is used in communication and interaction with users. This research is intended to know quality of UPI Central Library Website relation with user satisfaction, especially bachelor students of Indonesia University of Education in the main campus of Bumi Siliwangi. One method of measuring the quality of a website can be done by using WebQual. This study uses the WebQual 4.0 method as the basis for measuring the quality of the web proposed by Barnes \& Vidgen which consists of of usability, information quality, and service interaction quality. Meanwhile in order to measure user satisfaction uses the theory of importance-performance analysis by Martilla and James which consist of importance and performance. The method is use is Quantitative Method with correlational treatment Pearson Product Moment which is intended to treat causality between $X$ and $Y$ variables. The collecting data technique used questionnaires, interviews and literature studies. Sampling was conducted by simple random sampling technique using a population of 27,172 students and respondents as many as 394 students. The results of this study indicate that the web quality of the UPI Central Library on user satisfaction has a significant relationship, which means that the higher the quality of the web, the higher the satisfaction received.
\end{abstract}

Keywords: Website quality; UPI Central Library; user satisfaction; Indonesia University of Education

\section{PENDAHULUAN}

Saat ini, perkembangan teknologi informasi mengalami perubahan yang cepat yang membuat setiap individu dapat mengakses informasi secara luas dan beragam. Dalam mengakses informasi tersebut membutuhkan wadah sebagai media akses yaitu internet. Internet terhubung dengan jaringan telekomunikasi sebagai alat pencarian informasi yang dapat diakses kapanpun dan dimanapun dengan tujuan untuk pemenuhan kebutuhan informasi. Penggunaan internet di Indonesia telah mengalami peningkatan secara kontinu. Hal ini dapat dijelaskan dengan data survey yang dilakukan oleh Asosiasi Penyelenggara Jasa Internet Indonesia (APJII) pada 2017 menyatakan bahwa pengguna internet mengalami peningkatan dari tahun 2016 menjadi 143,26 juta jiwa atau setara $54,7 \%$ yang sebelumnya hanya 132,7 juta jiwa.

Perkembangan internet menyebabkan instansi termasuk perpustakaan untuk merubah sistem dan menyesuaikan dengan perkembangan zaman. Salah satu bentuk dari perkembangan internet dan teknologi informasi perpustakaan diwujudkan dengan website yang berfungsi sebagai bagian kegiatan promosi, layanan informasi, dan membantu mahasiswa dalam pemenuhan kebutuhan informasi dengan maksud dapat memberikan kenyamanan dan kepuasan pengguna.

Konsep kepuasan pengguna itu sendiri merupakan suatu keadaan dimana pengguna mempunyai suatu keinginan, harapan, dan persepsi terhadap suatu layanan yang ada di sebuah perpustakaan. Sebuah layanan dapat dianggap memuaskan pengguna apabila layanan tersebut dapat memenuhi kebutuhan dan harapan pengguna (user oriented). Sivitas akademika atau elemen mahasiswa dalam menentukan kepuasan sebuah 
pelayanan yang ada di perguruan tinggi merupakan sebuah elemen yang harus diperhitungkan sebagai dasar pengukuran tingkat kualitas layanan perpustakaan dalam menyediakan layanan yang lebih baik, efisien dan efektif. Menurut Erwina \& Yanto (2017), salah satu aktivitas perpustakaan perguruan tinggi adalah menghubungkan komunikasi ilmiah dalam mendisemikan karya ilmiah yang telah dipublikasikan kepada masyarakat luas atau sivitas akademika. Berdasarkan hal tersebut, perpustakaan memiliki tugas atau acuan dalam kemudahan akses informasi karya ilmiah kepada pengguna.

Kemudian APJII juga menyatakan bahwa sebesar 93,8\% atau sebanyak 124,4 juta masyarakat memilih konten untuk diakses yaitu konten pendidikan. Dalam menjawab tantangan tersebut, perpustakaan Universitas Pendidikan Indonesia memberikan layanan akses informasi pendidikan kedalam website. Website tersebut dikenal dengan Website UPI Central Library. Website merupakan suatu media informasi yang dapat menampilkan informasi-informasi secara luas dan lengkap yang dibutuhkan oleh lembaga atau institusi termasuk lembaga-lembaga informasi seperti perpustakaan, kearsipan ataupun museum. Informasi-informasi dalam web dapat diakses secara luas dikarenakan informasi tersebut tersebar secara global melalui situs web.

Website UPI Central Library merupakan suatu sistem website yang berbasis pada web discovery. Menurut Rufaidah (2018) bahwa web discovery merupakan suatu layanan perpustakaan berbasis web yang dimanfaatkan sebagai langkah membantu kemudahan pengguna dalam mengakses informasi di sebuah perpustakaan yang diakses menggunakan komputer. Web UPI Central library merupakan wadah bagi Universitas Pendidikan Indonesia menyimpan informasi-informasi ilmiah yang dapat dimanfaatkan kedepannya bagi ilmu pengetahuan terutama sivitas akademika. Pada penelitian ini berfokus pada website HTTP://PERPUSTAKAANUPI.EDU/ dan HTTP://REPOSITORY.UPI.EDU/ sebagai web discovery UPI. Website UPI Central Library merupakan laman penelusuran informasi yang memuat konten-konten perpustakaan UPI seperti Catalog Online, E-Journal, EBook, Digital Repository, dan Layanan Mandiri.

Permasalahan yang terjadi pada suatu instansi mengenai web ialah belum adanya pengukuran kualitas web dengan memperhatikan kepuasan pengguna yang berdasar pada ekspekstasi dan tingkat kinerja web. Dalam observasi yang telah dilakukan, didapatkan bahwa belum adanya penelitian yang melakukan pengukuran kualitas website di UPI Central Library. Penelitian ini penting dan perlu untuk dilakukan sebagai suatu evaluasi mengenai kualitas website yang dapat dimanfaatkan sebagai sebuah pertimbangan bagi pimpinan atau perpustakaan untuk pengembangan website itu sendiri. Kualitas website saat ini menjadi suatu isu strategis yang digunakan dalam komunikasi dan interaksi dengan pengguna. Salah satu metode pengukuran kualitas website dapat dilakukan dengan menggunakan WebQual. Evaluasi terhadap pengukuran kualitas website dapat 
dilakukan dengan beberapa metode pengukuran, salah satu metode yang dapat digunakan untuk mengukur suatu kualitas website yaitu menggunakan metode WebQual 4.0.

Penelitian terhadap pengukuran kualitas website menggunakan WebQual 4.0 sudah banyak dilakukan oleh peneliti-peneliti terdahulu. Penelitian WebQual dikembangkan oleh Stuart Barnes dan Richard Vidgen pada 1998. Menurut Barnes \& Vidgen (2000) WebQual 4.0 merupakan suatu metode pengukuran kualitas website yang menggunakan tiga indikator utama yaitu usability, information quality, dan Interaction Service. Konsep dari WebQual 4.0 berdasar pada Quality Function Deployment (QFD) yaitu suatu proses yang berdasar pada "Voice of the Website User" dalam pengembangan dan implementasi pada produk atau jasa yang dimuat dalam web dengan menggunakan kuesioner dimana konsep tersebut berdasar pada persepsi pengguna akhir "end user" terhadap suatu website lembaga/institusi. Kemudian disesuaikan dengan apa yang dirasakan (performance) dan apa yang diharapkan (importance) pengguna yang mendukung kepuasan pengguna tersebut. Penelitian ini dilakukan karena belum adanya evaluasi melalui pengukuran website UPI Central Library, penelitian ini diperkuat dengan penelitian sejenis pernah dilakukan oleh Alhasanah (2014) yang menjelaskan bahwa pengukuran website yang dilakukan oleh pengguna dapat membantu perusahaan dalam mengembangkan dan meningkatkan kualitas website seperti pemeliharaan dan perbaikan website serta peningkatan layanan kepada pengguna.

Berdasarkan dari latar belakang yang telah disampaikan dan penelusuran yang dilakukan, belum ada yang melakukan penelitian terkait dengan kualitas website perpustakaan Universitas Pendidikan Indonsesia dengan kepuasan pengguna yang didasari persepsi dan harapan dari pengguna menggunakan metode WebQual 4.0. Tujuan dari penelitian ini adalah untuk mengetahui sejauh mana web UPI Central Library yang sedang berjalan sudah sesuai dengan kebutuhan dan keperluan pengguna dan peranan keterkaitan antara kualitas web dengan kepuasan pengguna yang dilakukan dengan pengukuran antar variabel. Oleh karena itu, peneliti tertarik lebih lanjut untuk mengetahui apakah website perpustakaan UPI sudah sesuai dengan persepsi dan harapan dari pengguna dengan judul "Hubungan Kualitas Website UPI Central Library dengan Kepuasan Pengguna”.

\section{METODE PENELITIAN}

Metode penelitian ini menggunakan metode penelitian kuantitatif dengan pendekatan korelasional. Pendekatan korelasional digunakan untuk mencari hubungan antar variabel dan sejauh mana hubungan yang dimiliki antar variabel. Menurut Hasan (2002), pendekatan korelasional merupakan pendekatan yang digunakan untuk menentukan keterkaitan antar dua variabel atau lebih, untuk mengetahui sejauh mana tingkat hubungan tersebut dengan melakukan pengumpulan data. Pada penelitian ini 
ditujukan untuk mengetahui sejauh mana hubungan kualitas website UPI Central Library dengan kepuasan pengguna.

Populasi yang digunakan dalam penelitian ini yaitu mahasiswa Strata I Universitas Pendidikan Indonesia Kampus Bumi Siliwangi. Data tersebut terhitung per tahun akademik 2019/2020 sebanyak 26.172 mahasiswa. Sedangkan sampel yang digunakan sebanyak 394 responden dengan menggunakan teknik sampling acak sederhana (simple random sampling). William G. Cochran dalam Prijana, Winoto, \& Yanto (2016) menjelaskan bahwa sampling acak sederhana (simple random sampling) merupakan sampling yang diambil dari seluruh total responden yang diacak seluruhnya dan setiap responden memiliki peluang yang sama untuk dipilih. Pemilihan dilakukan dengan tabel angka random atau menggunakan program komputer. Jenis data yang digunakan dalam penelitian ini yakni data primer dan data sekunder. Sedangkan teknik pengumpulan data terdiri dari kuesioner, wawancara dan studi kepustakaan.

Analisis data yang dilakukan terbagi menjadi analisis statistik deskriptif untuk menganalisis data yang diperoleh dan analisis inferensial untuk menguji hipotesis dan korelasi. Uji korelasi dilakukan dengan metode korelasi pearson product moment dengan derajat kepercayaan 90\%. Uji korelasi Pearson Product Moment bertujuan untuk menguji hubungan sebab akibat antara variabel $\mathrm{X}$ dan variabel $\mathrm{Y}$. Menurut Prijana, Winoto, \& Yanto (2016), syarat skala yang digunakan dalam uji korelasi pearson product moment yaitu menggunakan skala interval sebagai aturan pengukuran statistiknya.

Setelah mendapatkan hasil dari perhitungan uji korelasi pearson product moment, maka dilanjutkan dengan uji signifikan. Rumus untuk melakukan uji signifikansi menurut Prijana, Winoto, \& Yanto (2016), adalah sebagai berikut:

$$
\text { thitung }=\frac{\rho \sqrt{n-2}}{\sqrt{1-\rho^{2}}}
$$

Hasil perhitungan thitung akan dibandingkan dengan tabel. Apabila hasil thitung $>$ tabel maka memiliki arti arti $\mathrm{H}_{1}$ diterima dan $\mathrm{H}_{0}$ ditolak bahwa terdapat hubungan antar variabel dan sebaliknya.

\section{HASIL DAN PEMBAHASAN}

Website UPI Central library merupakan wadah bagi Universitas Pendidikan Indonesia untuk menyimpan informasi-informasi ilmiah yang dapat dimanfaatkan kedepannya bagi ilmu pengetahuan terutama sivitas akademika. Website UPI Central Library merupakan suatu sistem website yang berbasis pada web discovery yang merupakan layanan di perpustakaan yang berbasi web untuk memudahkan kegiatan mengakses informasi di perpustakaan dengan bantuan komputer. Dari hasil penelitian, terdapat beberapa hubungan antar kualitas website UPI Central Library dengan kepuasan 
para pengguna khususnya untuk mahasiwa Strata I Universitas Pendidikan Indonesia, yaitu sebagai berikut.

Tabel 1. Hubungan antara Kualitas Website UPI Central Library dengan Kepuasan Pengguna pada Mahasiswa Strata 1 Universitas Pendidikan Indonesia

\begin{tabular}{|c|c|c|c|c|}
\hline \multicolumn{5}{|c|}{$\mathrm{X} \rightarrow \mathrm{Y}$} \\
\hline \multicolumn{5}{|c|}{ Correlations } \\
\hline & & & Kualitas & Kepuasan \\
\hline & & & Website & Pengguna \\
\hline \multirow[t]{4}{*}{ Kualitas Website } & \multicolumn{2}{|c|}{ Pearson } & 1 & ,507" \\
\hline & \multicolumn{2}{|c|}{ Correlation } & & \\
\hline & \multicolumn{2}{|c|}{ Sig. (2-tailed) } & & ,000 \\
\hline & \multicolumn{2}{|c|}{$\mathrm{N}$} & 394 & 394 \\
\hline \multirow[t]{4}{*}{ Kepuasan Pengguna } & \multicolumn{2}{|c|}{ Pearson } & ,507"* & 1 \\
\hline & \multicolumn{2}{|c|}{ Correlation } & & \\
\hline & \multicolumn{2}{|c|}{ Sig. (2-tailed) } & ,000 & \\
\hline & \multicolumn{2}{|c|}{$\mathrm{N}$} & 394 & 394 \\
\hline \multirow{5}{*}{0,507} & thitung & ttabel & Kesimpulan & \\
\hline & \multirow{4}{*}{11,645} & \multirow{4}{*}{1,650} & Terdapat & \\
\hline & & & hubungan & \\
\hline & & & signifikan yang & \\
\hline & & & cukup kuat & \\
\hline
\end{tabular}

Sumber: Pengolahan data oleh Peneliti (2019)

Berdasarkan hasil pengujian statistik diketahui bahwa kualitas website UPI Central Library cenderung memberikan dampak positif pada kepuasan, hal ini dibuktikan dengan penghitungan yang menghasilkan nilai koefisien korelasi positif sebesar 0,507 artinya semakin tinggi kualitas website UPI Central Library maka semakin terpenuhinya kepuasan pengguna. Hasil tersebut menunjukkan keeratan hubungan antara kualitas website UPI Central Library dengan tingkat kepentingan kepuasan pengguna pada mahasiswa strata 1 Universitas Pendidikan Indonesia memiliki hubungan dalam kategori cukup kuat karena berada diantara 0,40 - 0,599.

Webqual merupakan salah satu metode yang digunakan untuk pengukuran kualitas website. Metode webqual merupakan sebuah pengembangan dari metode servqual yang digunakan sebagai metode pengukuran kualitas suatu layanan. Menurut Barnes \& Vidgen (2002) menjelaskan bahwa webqual 4.0 merupakan sebuah metode yang difungsikan untuk mengukur sejauh mana kualitas dari sebuah webite. Webqual 4.0 terbagi menjadi 3 indikator yaitu usability quality (kualitas ketergunaan), information quality (kualitas informasi), serta interaction service quality (kualitas layanan interaksi). 
Atribut dari kualitas ketergunaan yaitu web mudah dipelajari, informasi jelas dan mudah dipahami, mudah melakukan navigasi, web mudah digunakan, tampilan menarik, desain web sesuai dengan tipenya, web dapat diakses setiap saat dan menciptakan pengalaman positif. Atribut dari kualitas informasi yaitu web menyediakan informasi yang akurat, informasi dapat dipercaya, informasi yang terkini, informasi yang relevan, informasi yang mudah dipahami, informasi yang lengkap, dan web sudah sesuai dengan format sebagai penyedia informasi. Kemudian atribut dari kualitas layanan interaksi yaitu web mempunyai reputasi baik, keamanan saat interaksi, keamanan terhadap informasi pribadi, pencarian terhadap kata kunci, memberikan ruang untuk kelompok atau komunitas, mudah berkomunikasi dengan organisasi, dan memberikan informasi layanan dengan jelas. Konsep yang terdapat dalam WebQual 4.0 mempunyai fokus utama dengan melibatkan pengguna pada proses pengembangan serta penerapan pada layanan yang diberikan.

Dalam proses melibatkan pengguna tentu diharapkan adanya sebuah kepuasan yang dirasakan terhadap suatu website. Importance Performance Analysis (IPA) merupakan sebuah metode yang dapat diterapkan untuk mengukur kepuasan pengguna terhadap suatu barang atau jasa. Santoso, Budi (2015) menjelaskan bahwa Fungsi utama dari IPA yaitu untuk menentukan apa-apa saja yang mempengaruhi kepuasan dan loyalitas dari pengguna dengan cara menampilkan informasi yang berkaitan dengan faktor-faktor atau indikator-indikator pelayanan. Dalam mengukur kepuasan pengguna pada website UPI Central Library, IPA dapat dilakukan dengan menggunakan mengidentifikasi hal-hal yang diinginkan/ideal/tingkat kepentingan (importance) dengan hal-hal yang dirasakan/ aktual/tingkat kinerja (performance) terhadap web.

Secara garis besar, kualitas web UPI Central Library dengan kepuasan pengguna dapat dikatakan baik. Hal ini dapat dilihat dari hasil hipotesis yang dilakukan. Dalam melihat hubungan antara kualitas web UPI Central Library dengan kepuasan pengguna dapat dilihat dari hasil perhitungan thitung $(11,645) \geq$ tabel $(1,650)$ yang artinya kualitas kegunaan website UPI Central Library berhubungan signifikan dengan tingkat kinerja bagi mahasiswa strata 1 Universitas Pendidikan Indonesia. Dengan demikian, secara kualitas web UPI Central Library telah mampu menjadi website perpustakaan yang baik dan dapat memenuhi kepuasan pengguna. Meskipun demikian, web UPI Central Library tetap harus berkembang dan ditingkatkan kembali sehingga kepuasan pengguna akan semakin tinggi. Hal ini sejalan dengan penelitian yang dilakukan oleh Fazrin (2017) bahwa kualitas web. 
Tabel 2. Hubungan antara Kualitas Ketergunaan Website UPI Central Library dengan Tingkat Kepentingan pada Mahasiswa Strata 1 Universitas Pendidikan Indonesia

$\mathrm{X}_{1} \rightarrow \mathrm{Y}_{1}$

\begin{tabular}{|c|c|c|c|}
\hline \multicolumn{3}{|c|}{$\mathrm{X}_{1} \rightarrow \mathrm{Y}_{1}$} & Correlations \\
\hline & & Kualitas & Tingkat \\
\hline & & Kegunaan & Kepentingan \\
\hline \multirow[t]{3}{*}{ Kualitas Kegunaan } & Pearson Correlation & 1 & ,305" \\
\hline & Sig. (2-tailed) & &, 000 \\
\hline & $\mathrm{N}$ & 394 & 394 \\
\hline \multirow[t]{3}{*}{ Tingkat Kepentingan } & Pearson Correlation & ,305" & 1 \\
\hline & Sig. (2-tailed) & ,000 & \\
\hline & $\mathrm{N}$ & 394 & 394 \\
\hline
\end{tabular}

**. Correlation is significant at the 0.01 level (2-tailed).

\begin{tabular}{|c|c|c|c|}
\hline$\rho$ & thitung & ttabel & Kesimpulan \\
\hline 0,305 & 6,343 & 1,650 & $\begin{array}{c}\text { Terdapat } \\
\text { hubungan } \\
\text { signifikan yang } \\
\text { rendah }\end{array}$ \\
\hline
\end{tabular}

Sumber: Pengolahan data oleh Peneliti (2019)

Berdasarkan hasil pengujian statistik diketahui bahwa nilai ketergunaan website UPI Central Library cenderung memberikan dampak positif pada tingkat kepentingan pengguna, hal ini dibuktikan dengan penghitungan yang menghasilkan nilai koefisien korelasi positif sebesar 0,305 artinya semakin tinggi kualitas ketergunaan website UPI Central Library maka semakin terpenuhinya tingkat kepentingan pengguna. Hasil tersebut menunjukkan keeratan hubungan antara kualitas kegunaan website UPI Central Library dengan tingkat kepentingan pengguna pada mahasiswa strata 1 Universitas Pendidikan Indonesia memiliki hubungan dalam kategori rendah karena berada diantara $0,20-0,399$.

Kualitas ketergunaan merupakan salah satu metode untuk pengukuran kualitas website yaitu sejauh mana suatu penggunaan informasi yang dihasilkan website UPI Central Library mampu memberikan kemudahan dalam penggunaan website itu sendiri yang mencakup kemudahan untuk dipelajari, dipahami, dioperasikan, dan kemudahan dalam navigasi dan memberikan nilai positif kepada pengguna. Menurut Barnes dan Vidgen (2002) Usability Quality/ kualitas ketergunaan merupakan sebuah kategori yang diukur melalui situs web tersebut yang mencakup hubungan yang dilakukan antara manusia dan komputer serta ketergunaannya diantaranya mengenai desain tampilan 
website tersebut, kemudahan dalam melakukan navigasi, kemudahan dalam memahami mempelajari dan mengoperasikan website tersebut serta memberikan nilai positif bagi para pengguna/ pengunjung. Tingkat kepentingan pengguna menentukan apa yang menjadi ekspektasi dari pengguna artinya dalam menentukan kualitas ketergunaan juga harus memperhatikan tingkat kepentingan atau ekspektasi dari pengguna untuk menentukan kepuasan pengguna terhadap kualitas ketergunaan. Hasil perhitungan thitung $(6,343) \geq$ tabel $(1,650)$ yang artinya kualitas kegunaan website UPI Central Library berhubungan signifikan dengan tingkat kepentingan kepuasan pengguna bagi mahasiswa strata 1 Universitas Pendidikan Indonesia.

Secara garis besar, kualitas ketergunaan website UPI Central Library dengan tingkat kepentingan pengguna dapat dikatakan baik. Hal ini dapat dilihat dari hasil pengujian hipotesis yang telah dilakukan. Dalam penelitian ini juga menunjukkan ratarata nilai yang cukup dari kualitas ketergunaan (usability quality) yang diberikan oleh responden yaitu 3,75 dari skala 1-5. Sedangkan untuk tingkat kepentingan (importance) menunjukkan rata-rata nilai yang cukup juga yaitu 3,67 dari skala 1-5. Hal tersebut berarti tingkat kepentingan pengguna sudah cukup terpenuhi terhadap kualitas ketergunaan. Maka dari itu dapat ditarik kesimpulan bahwa pihak pengembang website UPI Central Library masih perlu meningkatkan kembali aspek ketergunaan dan juga harus dipahami bahwa pengguna memperdulikan aspek ketergunaan tersebut sehingga dapat memenuhi hal yang diinginkan dan diharapkan pengguna.

Tabel 3. Hubungan antara Kualitas Ketergunaan Website UPI Central Library dengan Tingkat Kinerja bagi Mahasiswa Strata 1 Universitas Pendidikan Indonesia Kampus Bumi Siliwangi

$$
\mathrm{X}_{1} \rightarrow \mathrm{Y}_{2}
$$

\begin{tabular}{cccc}
\multicolumn{4}{c}{$\mathrm{X}_{1} \rightarrow \mathrm{Y}_{2}$} \\
& & & \\
\hline & & Kualitas & Tingkat Kinerja \\
& & Kegunaan & \\
\hline Kualitas Kegunaan & Pearson Correlation & 1 &, $398^{* \prime}$ \\
& Sig. (2-tailed) & &, 000 \\
N & 394 & 394 \\
\hline Tingkat Kinerja & Pearson Correlation &, $398^{* *}$ & 1 \\
& Sig. (2-tailed) &, 000 & 394 \\
& $\mathrm{~N}$ & 394 & \\
\hline
\end{tabular}

**. Correlation is significant at the 0.01 level (2-tailed). 


\begin{tabular}{cccc}
\hline $\boldsymbol{\rho}$ & thitung & ttabel & Kesimpulan \\
\hline 0,398 & 8,584 & 1,650 & $\begin{array}{c}\text { Terdapat } \\
\text { hubungan } \\
\text { signifikan yang } \\
\text { rendah }\end{array}$ \\
\hline \multicolumn{3}{l}{ Sumber: Pengolahan data oleh Peneliti (2019) }
\end{tabular}

Berdasarkan hasil pengujian statistik diketahui bahwa nilai ketergunaan website UPI Central Library cenderung memberikan dampak positif pada tingkat kepentingan pengguna, hal ini dibuktikan dengan penghitungan menggunakan rumus Pearson Product Moment dengan derajat kepercayaan 90\% yang menghasilkan nilai koefisien korelasi positif sebesar 0,305 artinya semakin tinggi kualitas ketergunaan website UPI Central Library maka semakin terpenuhinya tingkat kepentingan pengguna. Hasil tersebut menunjukkan keeratan hubungan antara kualitas kegunaan website UPI Central Library dengan tingkat kepentingan pengguna pada mahasiswa strata 1 Universitas Pendidikan Indonesia memiliki hubungan dalam kategori rendah karena berada diantara 0,20-0,399.

Kualitas ketergunaan merupakan salah satu metode untuk pengukuran kualitas website yaitu sejauh mana suatu penggunaan informasi yang dihasilkan website UPI Central Library mampu memberikan kemudahan dalam penggunaan website itu sendiri yang mencakup kemudahan untuk dipelajari, dipahami, dioperasikan, dan kemudahan dalam navigasi dan memberikan nilai positif kepada pengguna. Menurut Barnes dan Vidgen (2002) Usability Quality/ kualitas ketergunaan merupakan sebuah kategori yang diukur melalui situs web tersebut yang mencakup hubungan yang dilakukan antara manusia dan komputer serta ketergunaannya diantaranya mengenai desain tampilan website tersebut, kemudahan dalam melakukan navigasi, kemudahan dalam memahami mempelajari dan mengoperasikan website tersebut serta memberikan nilai positif bagi para pengguna atau pengunjung. Tingkat kepentingan pengguna menentukan apa yang menjadi ekspektasi dari pengguna artinya dalam menentukan kualitas ketergunaan juga harus memperhatikan tingkat kepentingan atau ekspektasi dari pengguna untuk menentukan kepuasan pengguna terhadap kualitas ketergunaan. Hasil perhitungan thitung $(6,343) \geq$ tabel $(1,650)$ yang artinya kualitas kegunaan website UPI Central Library berhubungan signifikan dengan tingkat kepentingan kepuasan pengguna bagi mahasiswa strata 1 Universitas Pendidikan Indonesia.

Secara garis besar, kualitas ketergunaan website UPI Central Library dengan tingkat kepentingan pengguna dapat dikatakan baik. Hal ini dapat dilihat dari hasil pengujian hipotesis yang telah dilakukan. Dalam penelitian ini juga menunjukkan ratarata nilai yang cukup dari kualitas ketergunaan (usability quality) yang diberikan oleh responden yaitu 3,75 dari skala 1-5. Sedangkan untuk tingkat kepentingan (importance) menunjukkan rata-rata nilai yang cukup juga yaitu 3,67 dari skala 1-5. Hal tersebut berarti tingkat kepentingan pengguna sudah cukup terpenuhi terhadap kualitas 
ketergunaan. Maka dari itu dapat ditarik kesimpulan bahwa pihak pengembang web UPI Central Library masih perlu meningkatkan kembali aspek ketergunaan dan juga harus dipahami bahwa pengguna memperdulikan aspek ketergunaan tersebut sehingga dapat memenuhi hal yang diinginkan dan diharapkan pengguna.

Tabel 4. Hubungan antara Kualitas Informasi Website UPI Central Library dengan Tingkat Kepentingan bagi Mahasiswa Strata 1 Universitas Pendidikan Indonesia Kampus Bumi Siliwangi

$\mathrm{X}_{2} \rightarrow \mathrm{Y}_{1}$

\begin{tabular}{|c|c|c|c|c|}
\hline \multicolumn{5}{|c|}{ Correlations } \\
\hline & & & Kualitas & Tingkat \\
\hline & & & Informasi & Kepentingan \\
\hline \multirow[t]{3}{*}{ Kualitas Informasi } & \multicolumn{2}{|c|}{ Pearson Correlation } & 1 & ,241" \\
\hline & \multicolumn{2}{|c|}{ Sig. (2-tailed) } & &, 000 \\
\hline & \multicolumn{2}{|c|}{$\mathrm{N}$} & 394 & 394 \\
\hline \multirow[t]{3}{*}{ Tingkat Kepentingan } & \multicolumn{2}{|c|}{ Pearson Correlation } & ,241" & 1 \\
\hline & \multicolumn{2}{|c|}{ Sig. (2-tailed) } & ,000 & \\
\hline & \multicolumn{2}{|c|}{$\mathrm{N}$} & 394 & 394 \\
\hline \multicolumn{5}{|c|}{ **. Correlation is significant at the 0.01 level (2-tailed). } \\
\hline$\rho$ & thitung & tabel & Kesimpulan & \\
\hline 0,241 & 4,915 & 1,650 & $\begin{array}{c}\text { Terdapat } \\
\text { hubungan } \\
\text { signifikan yang } \\
\text { rendah }\end{array}$ & \\
\hline Sumbe & Pengola & a ole & eneliti (2019) & \\
\hline
\end{tabular}

Berdasarkan hasil pengujian statistik diketahui bahwa nilai kualitas informasi website UPI Central Library cenderung memberikan dampak positif pada tingkat kepentingan kepuasan pengguna, hal ini dibuktikan dengan penghitungan yang menghasilkan nilai koefisien korelasi positif sebesar 0,241 artinya semakin tinggi kualitas ketergunaan website UPI Central Library maka semakin terpenuhinya tingkat kepentingan pengguna. Hasil tersebut menunjukkan keeratan hubungan antara kualitas informasi website UPI Central Library dengan tingkat kepentingan pengguna pada mahasiswa strata 1 Universitas Pendidikan Indonesia memiliki hubungan dalam kategori rendah karena berada diantara 0,20 - 0,399.

Menurut Barnes \& Vidgen (2002) information quality/kualitas informasi merupakan kategori yang mengkaji isi dari kualitas informasi atau konten secara umum yang mencakup kelayakan informasi tersebut terhadap tujuan dari pengguna diantaranya 
mengenai informasi yang akurat, dapat dipercaya, up to date, serta relevansi dalam penyajiannya. Informasi dapat dikatakan berkualitas apabila informasi mudah untuk diterima dan dicerna oleh penggunanya. Agar informasi tersebut dapat dengan mudah diterima oleh pengguna perlu memperhatikan tingkat kepentingan pengguna yaitu informasi seperti apa saja yang dibutuhkan oleh pengguna. Tingkat kepentingan dapat mengontrol mengenai informasi website apa saja yang harus disediakan kedepannya guna memenuhi kebutuhan informasi pengguna. Hal tersebut akan diuji menggunakan thitung. Hasil perhitungan thitung $(4,915) \geq$ ttabel $(1,650)$ yang artinya kualitas kegunaan website UPI Central Library berhubungan signifikan dengan tingkat kepentingan pengguna bagi mahasiswa strata 1 Universitas Pendidikan Indonesia.

Secara garis besar, kualitas informasi website UPI Central Library dengan tingkat kepentingan pengguna dapat dikatakan baik. Hal ini dapat dilihat dari hasil pengujian hipotesis yang telah dilakukan. Dalam penelitian ini juga menunjukkan rata-rata nilai yang cukup dari kualitas informasi (information quality) yang diberikan oleh responden yaitu 3,78 dari skala 1-5. Sedangkan untuk tingkat kepentingan (importance) menunjukkan rata-rata nilai yang cukup juga yaitu 3,67 dari skala 1-5. Hal tersebut berarti tingkat kepentingan pengguna sudah cukup terpenuhi terhadap kualitas informasi. Maka dari itu dapat ditarik kesimpulan bahwa pihak pengembang website UPI Central Library masih perlu meningkatkan kembali aspek informasi dan juga harus dipahami bahwa pengguna memperdulikan aspek ketergunaan tersebut sehingga dapat memenuhi hal yang diinginkan dan diharapkan pengguna dikarenakan informasi merupakan isi dari website yang dapat digunakan pengguna untuk memenuhi kebutuhan informasi mereka.

Tabel 5. Hubungan antara Kualitas Informasi Website UPI Central Library dengan Tingkat Kinerja bagi Mahasiswa Strata 1 Universitas Pendidikan Indonesia Kampus Bumi Siliwangi $\mathrm{X}_{2} \rightarrow \mathrm{Y}_{2}$

\begin{tabular}{|c|c|c|c|}
\hline \multicolumn{4}{|c|}{ Correlations } \\
\hline & & Kualitas & Tingkat Kinerja \\
\hline & & Informasi & \\
\hline \multirow[t]{3}{*}{ Kualitas Informasi } & Pearson Correlation & 1 & ,433" \\
\hline & Sig. (2-tailed) & & ,000 \\
\hline & $\mathrm{N}$ & 394 & 394 \\
\hline \multirow[t]{3}{*}{ Tingkat Kinerja } & Pearson Correlation &, $433^{* *}$ & 1 \\
\hline & Sig. (2-tailed) & ,000 & \\
\hline & $\mathrm{N}$ & 394 & 394 \\
\hline
\end{tabular}

**. Correlation is significant at the 0.01 level (2-tailed). 


\begin{tabular}{cccc}
\hline $\boldsymbol{\rho}$ & thitung & tabel & Kesimpulan \\
\hline 0,433 & 9,504 & 1,650 & $\begin{array}{c}\text { Terdapat } \\
\text { hubungan } \\
\text { signifikan yang } \\
\text { cukup kuat }\end{array}$ \\
\hline
\end{tabular}

Sumber: Pengolahan data oleh Peneliti (2019)

Berdasarkan hasil pengujian statistik diketahui bahwa nilai kualitas informasi website UPI Central Library cenderung memberikan dampak positif pada tingkat kinerja web, hal ini dibuktikan dengan penghitungan yang menghasilkan nilai koefisien korelasi positif sebesar 0,433 artinya semakin tinggi kualitas informasi website UPI Central Library maka semakin terpenuhinya tingkat kinerja website. Hasil tersebut menunjukkan keeratan hubungan antara kualitas ketergunaan website UPI Central Library dengan tingkat kinerja website pada mahasiswa strata 1 Universitas Pendidikan Indonesia memiliki hubungan dalam kategori sedang karena berada diantara 0,40 - 0,599.

Kualitas informasi berhubungan dengan pemenuhan kebutuhan informasi artinya semakin tinggi kualitas informasi maka akan semakin terpenuhi juga kebutuhan informasinya. Hal ini sesuai dengan penelitian yang dilakukan Rufaidah (2018) yang menjelaskan adanya hubungan antara kualitas informasi dengan pemenuhan kebutuhan informasi bagi pengguna. Pemenuhan kebutuhan informasi merupakan pemenuhan sebuah kekosongan dalam diri seseorang, dalam hal ini kekosongan akan informasi atau pengetahuan. Tingkat kinerja menjelaskan mengenai penilaian pengguna akan pelayanan yang disajikan oleh perpustakaan. Informasi yang disajikan tentu menjadi pertimbangan pengguna dalam memilih informasi tersebut untuk memenuhi kebutuhannya. Dalam pemenuhan kebutuhan informasi maka tingkat kinerja harus diperhatikan. Hal ini dapat dibuktikan dengan hasil perhitungan thitung $(9,504) \geq$ ttabel $(1,650)$ yang artinya kualitas informasi website UPI Central Library berhubungan signifikan dengan tingkat kinerja web bagi mahasiswa strata 1 Universitas Pendidikan Indonesia.

Secara garis besar, kualitas informasi website UPI Central Library dengan tingkat kinerja web dapat dikatakan baik. Hal ini dapat dilihat dari hasil pengujian hipotesis yang telah dilakukan. Dalam penelitian ini juga menunjukkan rata-rata nilai yang cukup pada Y3.2 dengan pernyataan kepuasan mengenai kinerja pada kualitas informasi website yaitu 3,76 dari skala 1-5.Maka dari itu dapat ditarik kesimpulan bahwa tingkat kinerja pada kualitas informasi website UPI Central Library sudah cukup terpenuhi. Meskipun demikian, pengguna juga memberikan respon masih perlunya pengembangan untuk informasi terkini karena mendapatkan nilai rata-rata paling rendah yaitu 3,67. Hal ini menandakan bahwa informasi yang disajikan dalam website UPI Central Library masih 
belum sepenuhnya memberikan informasi yang up to date untuk memenuhi kebutuhan informasinya.

Tabel 6. Hubungan antara Kualitas Layanan Interaksi Website UPI Central Library dengan Tingkat

\begin{tabular}{|c|c|c|c|c|}
\hline \multicolumn{5}{|c|}{$\begin{array}{c}\text { Kepentingan } \\
\mathrm{X}_{3} \rightarrow \mathrm{Y}_{1}\end{array}$} \\
\hline \multicolumn{5}{|c|}{ Correlations } \\
\hline & & & Kualitas & Tingkat \\
\hline & & & Layanan & Kepentingan \\
\hline & & & Interaksi & \\
\hline \multirow[t]{3}{*}{ Kualitas Layanan Interaksi } & Pears & Correlation & 1 & ,333" \\
\hline & & -tailed) & &, 000 \\
\hline & & $\mathrm{N}$ & 394 & 394 \\
\hline \multirow[t]{3}{*}{ Ekspektasi Pengguna } & Pears & Correlation & ,333" & 1 \\
\hline & & -tailed) & ,000 & \\
\hline & & $\mathrm{N}$ & 394 & 394 \\
\hline \multicolumn{5}{|c|}{ **. Correlation is significant at the 0.01 level (2-tailed). } \\
\hline$\rho$ & thitung & tabel & Kesimpulan & \\
\hline 0,333 & 6,992 & 1,650 & $\begin{array}{c}\text { Terdapat } \\
\text { hubungan } \\
\text { signifikan yang } \\
\text { cukup kuat }\end{array}$ & \\
\hline
\end{tabular}

Sumber: Pengolahan data oleh Peneliti (2019)

Berdasarkan hasil pengujian statistik diketahui bahwa nilai kualitas layanan interaksi website UPI Central Library cenderung memberikan dampak positif pada tingkat kepentingan pengguna, hal ini dibuktikan dengan penghitungan yang menghasilkan nilai koefisien korelasi positif sebesar 0,333 artinya semakin tinggi kualitas layanan interaksi website UPI Central Library maka semakin terpenuhinya tingkat kepentingan pengguna. Hasil tersebut menunjukkan keeratan hubungan antara kualitas layanan interaksi website UPI Central Library dengan tingkat kepentingan pengguna pada mahasiswa strata 1 Universitas Pendidikan Indonesia memiliki hubungan dalam kategori rendah karena berada diantara 0,20 - 0,399.

Menurut Barnes \& Vidgen (2002) service interaction quality/ kualitas layanan interaksi merupakan kategori pengukuran kualitas website melalui interaksi layanan yang dirasakan oleh pengguna diantaranya mengenai reputasi dari website tersebut, pemberian rasa aman dan rasa percaya pengguna ketika melakukan pengaksesan, serta pemberian 
ruang untuk melakukan komunikasi. Tingkat kepentingan didalam layanan interaksi mengacu pada pentingnya hal-hal yang dirasakan pengguna untuk bagaimana idealnya layanan interaksi pada website yang diinginkan pengguna. Dalam mengetahui sejauh mana hubungan antara kualitas layanan interaksi dilakukan dengan perhitungan thitung. Dalam perhitungan, thitung $(6,992) \geq$ ttabel $(1,650)$ yang artinya kualitas kegunaan website UPI Central Library berhubungan signifikan dengan tingkat kepentingan pengguna bagi mahasiswa strata 1 Universitas Pendidikan Indonesia.

Secara garis besar, kualitas layanan interaksi web UPI Central Library dengan tingkat kepentingan kepuasan pengguna dapat dikatakan baik. Hal ini dapat dilihat dari hasil pengujian hipotesis yang telah dilakukan. Dalam penelitian ini juga menunjukkan rata-rata nilai yang cukup dari kualitas layanan interaksi (interaction service quality) yang diberikan oleh responden yaitu 3,79 dari skala 1-5. Sedangkan untuk tingkat kepentingan (importance) menunjukkan rata-rata nilai yang cukup juga yaitu 3,67 dari skala 1-5. Hal tersebut berarti tingkat kepentingan pengguna sudah cukup terpenuhi terhadap kualitas informasi. Maka dari itu dapat ditarik kesimpulan bahwa pihak pengembang web UPI Central Library masih perlu meningkatkan kembali aspek layanan interaksi dan juga harus dipahami bahwa pengguna memperdulikan aspek layanan interkasi tersebut sehingga dapat memenuhi hal yang diinginkan dan diharapkan pengguna. Layanan interaksi selayaknya memberikan keamanan, kenikmatan dan kenyamanan bagi pengguna dalam menjelajahi website.

Tabel 7. Hubungan antara Kualitas Layanan Interaksi Website UPI Central Library dengan Tingkat Kinerja $\mathrm{X}_{3} \rightarrow \mathrm{Y}_{2}$

\begin{tabular}{cccc}
\hline & Correlations & & \\
\hline & & Kualitas \\
Layanan & Tingkat \\
Interaksi & \\
& & 1 &, $424^{* \prime}$ \\
\hline Kualitas Layanan Interaksi & Pearson Correlation &, 000 \\
& Sig. (2-tailed) & 394 & 394 \\
Tingkat Kinerja & Pearson Correlation &, $424 *$ & 1 \\
& Sig. (2-tailed) &, 000 & 394 \\
N & 394 \\
\hline
\end{tabular}




\begin{tabular}{cccc}
\hline $\boldsymbol{\rho}$ & thitung & ttabel & Kesimpulan \\
\hline 0,424 & 9,266 & 1,650 & $\begin{array}{c}\text { Terdapat } \\
\text { hubungan } \\
\text { signifikan yang } \\
\text { cukup kuat }\end{array}$ \\
\hline
\end{tabular}

Sumber: Pengolahan data oleh Peneliti (2019)

Berdasarkan hasil pengujian statistik diketahui bahwa nilai layanan interaksi website UPI Central Library cenderung memberikan dampak positif pada tingkat kinerja website, hal ini dibuktikan dengan penghitungan yang menghasilkan nilai koefisien korelasi positif sebesar 0,424 artinya semakin tinggi kualitas layanan interaksi website UPI Central Library maka semakin terpenuhinya tingkat kinerja kepuasan pengguna. Hasil tersebut menunjukkan keeratan hubungan antara kualitas layanan interaksi website UPI Central Library dengan tingkat kinerja web pada mahasiswa strata 1 Universitas Pendidikan Indonesia memiliki hubungan dalam kategori sedang karena berada diantara $0,40-0,599$.

Perlunya penilaian kinerja terhadap kualitas layanan interaksi guna memberikan kenyamanan bagi pengguna dalam menjelajahi website. Kualitas layanan interaksi menurut Santoso (2015) merupakan penilaian terhadap layanan yang disajikan website dalam pemenuhan kebutuhan informasi. Tingkat kinerja terhadap kualitas layanan interkasi yang dirasakan pengguna menunjukkan adanya kepuasan dengan rata-rata 3,74 pada indikator Y3 yang merupakan penilaian tingkat kinerja pada layanan interkasi. Semakin tinggi rata-rata tersebut maka tingkat kepuasan tersebut terpenuhi. Menurut Ellyusman (2017) berpendapat bahwa layanan interaksi sebenarnya tidak terlalu diperhatikan pengguna, namun tetap harus dilakukan pengukuran. Pengukuran ini dilakukan untuk mengetahui sejauh mana kualitas layanan interaksi berpengaruh terhadap pengguna. Hasil perhitungan thitung $(9,266) \geq$ tabel $(1,650)$ yang artinya kualitas kegunaan website UPI Central Library berhubungan signifikan dengan tingkat kinerja bagi mahasiswa strata 1 Universitas Pendidikan Indonesia.

Secara garis besar, kualitas layanan interaksi web UPI Central Library dengan tingkat kinerja web dapat dikatakan baik. Hal ini dapat dilihat dari hasil pengujian hipotesis yang telah dilakukan. Dalam penelitian ini juga menunjukkan rata-rata nilai yang cukup pada Y3.3 dengan pernyataan kepuasan mengenai kinerja pada kualitas layanan interaksi website yaitu 3,73 dari skala 1-5.Maka dari itu dapat ditarik kesimpulan bahwa tingkat kinerja pada kualitas informasi website UPI Central Library sudah cukup terpenuhi. Meskipun demikian, pengguna juga memberikan respon masih perlunya pengembangan untuk kemudahan dalam melakukan komunikasi dengan pihak organisasi/lembaga atau dalam hal ini perpustakaan karena mendapatkan nilai rata-rata 
paling rendah yaitu 3,64. Hal ini menandakan bahwa layanan interaksi yang disajikan dalam website UPI Central Library masih belum sepenuhnya memberikan akses kemudahan untuk melakukan komunikasi dengan perpustakaan untuk memenuhi kebutuhan informasinya. Website UPI Central Library memang memiliki fitur khusus untuk menyampaikan pesan kepada perpustakaan, namun beberapa responden mengeluh lamanya waktu untuk menanggapi pesan tersebut dan juga terkadang mengalami error yang menyebabkan pesan tidak dapat dikirim kepada perpustakaan.

\section{SIMPULAN}

Secara garis besar, maka kesimpulan dan hasil dari hipotesis mayor menunjukkan bahwa hubungan signifikan yang moderat antara kualitas website UPI Central Library dengan kepuasan moderat, signifikan dan searah artinya semakin tinggi kualitas website maka akan semakin tinggi pula kepuasan yang diterima. Adapun simpulan berdasarkan tujuan dari penelitian ini, pertama terdapat hubungan signifikan yang rendah antara kualitas ketergunaan website UPI Central Library dengan tingkat kepentingan pengguna, artinya semakin mudah dalam penggunaan website maka pula semakin besar apa yang diinginkan pengguna terhadap kemudahan dan user interface yang ada pada website. Kedua, terdapat hubungan signifikan yang rendah antara kualitas ketergunaan website UPI Central Library dengan tingkat kinerja website, artinya semakin mudah pengguna dalam menggunakan website maka semakin tinggi tingkat kinerja pada website. Ketiga, terdapat hubungan signifikan yang rendah antara kualitas informasi dengan tingkat kepentingan pengguna, artinya semakin akurat dan terpercaya informasi yang diberikan maka akan semakin besar apa yang diinginkan pengguna terhadap informasi yang disediakan.

Keempat, terdapat hubungan signifikan yang moderat antara kualitas infomasi dengan tingkat kinerja web, artinya semakin akurat dan terpercaya informasi yang diberikan maka semakin tinggi tingkat kinerja pada website. Kelima, terdapat hubungan signifikan yang rendah antara kualitas layanan interaksi website UPI Central Library dengan tingkat kepentingan pengguna, artinya semakin mudah pengguna dalam melakukan interaksi dengan website maka semakin besar harapan pengguna terhadap layanan interaksi yang disediakan. Keenam, terdapat hubungan signifikan yang moderat antara kualitas layanan interaksi website UPI Central Library dengan tingkat kinerja website, artinya semakin mudah pengguna dalam melakukan interaksi pada website maka semakin tinggi kinerja website.

\section{Kontribusi Pada Keilmuan}

Penelitian ini merupakan kajian dalam bidang ilmu informasi dan perpustakaan yang mengkaji bagaimana hubungan kualitas website UPI Central Library dengan kepuasan dari penggunanya yaitu mahasiswa strata 1 Universitas Pendidikan Indonesia. Penelitian ini berkaitan dengan bidang kajian pemasaran informasi 
dan teknologi informasi. Hasil penelitian ini dapat menjadi dasar untuk penelitian selanjutnya atau penelitian bidang sejenis mengenai hubungan kualitas website dengan kepuasan penggunanya. Penelitian ini juga dapat menjadi sumber inspirasi bagi penelitian pada bidang lain yang berhubungan dengan topik yang dibahas.

\section{Pernyataan Minat Kajian}

Peneliti bernama Ricky Hardiyanto memiliki minat kajian dalam bidang ilmu informasi dan perpustakaan. Peneliti bernama Ninis Agustini Damayani memiliki minat dalam kajian bidang pemasaran informasi, dan peneliti bernama Edwin Rizal memiliki minat dalam kajian di bidang teknologi informasi.

\section{Kontribusi Peneliti}

Peneliti melakukan pengumpulan data melalui kuesioner, wawancara dan studi literatur. Pengambilan sampling dilakukan dengan teknik sampel acak sederhana (simple random sampling), serta melakukan uji korelasi dengan dengan metode korelasi Pearson Product Moment.

\section{DAFTAR PUSTAKA}

Alhasanah, J. (2014). Pengaruh Kegunaan, Kualitas Informasi dan Interaksi Layanan Web E-Commerce Terhadap Keputusan Pembelian Online (Survei pada Konsumen www.getscoop.com). Jurnal Administrasi Bisnis S1 Universitas Brawijaya, 15(2). http://dx.doi.org/10.30829/jipi.v4i1.2917.

APJII. (2016). Profil Pengguna Internet Indonesia. Jakarta: Asosiasi Penyelenggara Jasa Internet Indonesia.

APJII. (2018). Survey APJII: Penetrasi Internet di Indonesia Capai 143 Juta Jiwa. Jakarta: Asosiasi Penyedia Jasa Internet Indonesia.

Barnes, S. J., \& Vidgen, R. (2000). WebQual: An Exploration of Web-Site Quality. ECIS 2000 Proceedings. 74. http://aisel.aisnet.org/ecis2000/74.

Barnes, S. J., \& Vidgen, R. (2003). Measuring Web Site Quality Improvement: A Case Study of The Forum on Strategic Management. Industrial Management \& Data System. Vol. 103 No. 5, pp. 297-309. https://doi.org/10.1108/02635570310477352

Ellyusman, S. (2017). Analisis Kualitas Sistem Informasi Akademik Menggunakan Metode Importance Performance Analysis (IPA) (Studi Kasus Pada Website Portal Akademik Universitas XYZ Bandung). Jurnal Kajian Informasi Dan Perpustakaan, 5(1). https://doi.org/10.24198/jkip.v5i1.11908

Erwina, W., \& Yanto, A. (2017). Portal Kandaga Universitas Padjadjaran Sebagai Mesin Pencari Perpustakaan-FINAL-REVISED. Bandung: Universitas Padjadjaran.

Fazrin, T. F. (2017). Pengaruh Kualitas Website Terhadap Citra Perpustakaan. Bandung: Universitas Padjadjaran.

Hasan, M. I. (2002). Pokok-pokok Materi Metodologi Penelitian dan Aplikasinya. Jakarta: Ghalia Indonesia. 
Martilla, J. A., \& James, J. C. (1977). Importance-Performance Analysis. Journal of Marketing. https://doi.org/10.1177/002224297704100112.

Prijana; Winoto, Yunus; Yanto, A. (2016). Metode Penelitian Kuantitatif: Ilmu Perpustakaan dan Informasi. Bandung: Unpad Press.

Puspitadewi, I., Erwina, W., \& Kurniasih, N. (2016). Pemanfaatan "Twitter Tmcpoldametro" dalam Memenuhi Kebutuhan Informasi Para Pengguna Jalan Raya. Jurnal Kajian Informasi Dan Perpustakaan, 4(1). https://doi.org/10.24198/jkip.v4i1.

Rachmawati, S. P. (2018). Pengaruh Kualitas Website Perpustakaan Terhadap Kepuasan Pengguna di Widyatama. Bandung: Universitas Padjadjaran.

Rufaidah, V. (2018). Hubungan Kualitas Web Kandaga Terhadap Kebutuhan Informasi Pengguna. Universitas Padjadjaran.

Santoso, B. S., Anwar, M., \& Hermawati, S. (2015). Analisis Kualitas Website Menggunakan Metode Webqual dan Importance-Performance Analysis pada Situs Kaskus. National Conference on Information Technology and Technical Engineering (CITEE). Yogyakarta: University Club Hotel Yogyakarta. UPI Central Library.

Perpustakaan UPI. Retrieved August 07, 2019 from UPI Central Libraryu: http://perpustakaan.upi.edu/profil-perpustakaan-upi/ 
